\title{
Calibration and validation of AquaCrop for irrigated peanut (Arachis hypogaea) in lowland rice systems of southern Laos
}

\author{
Khov, S. ${ }^{1}$, Vote, C. ${ }^{2}$, Hornbuckle, J. ${ }^{3}$, Inthavong, I. ${ }^{4}$, Oeurng, C. ${ }^{1}$, Sengxua, P. ${ }^{5}$, Sihathep, V. ${ }^{6}$, Song, L. ${ }^{1}$ \\ and Eberbach, $\mathbf{P} .^{2}$ \\ ${ }^{1}$ Institute of Technology of Cambodia, Department of Rural Engineering, Water Resources Engineering and \\ Rural Infrastructure, Phnom Penh, Cambodia \\ ${ }^{2}$ Graham Centre for Agricultural Innovation, Charles Sturt University, Wagga Wagga, NSW, Australia, \\ 2678 \\ ${ }^{3}$ Centre for Regional Futures, Deakin University, Griffith, NSW, Australia, 2680 \\ ${ }^{4}$ Research Centre for Climate Change Resilience in Agriculture, National Agriculture and Forestry \\ Research Institute, Vientiane, Lao PDR \\ ${ }^{5}$ Department of Agricultural Land Management, Vientiane, Lao PDR \\ ${ }^{6}$ Phone Ngam Rice Research Centre, Provincial Agriculture and Forestry Office, Pakse, Champasak, Lao \\ PDR \\ Email:cvote@csu.edu.au
}

\begin{abstract}
There are opportunities to enhance rural household incomes and improve nutritional status through the diversification of smallholder agricultural systems from wet season rice monoculture to the dryseason field and horticultural crop production e.g. maize, mung bean, soybean and peanut. In the semi-arid, rice-growing lowlands of southern Laos, there are a number of physiochemical soil constraints that prevent the successful production of non-rice cultivars in these systems which are further exacerbated by limited water supply. As a first assessment of yield potential, crop modelling offers a relatively inexpensive alternative to time-consuming, and often costly, field trials. However, in less developed regions, modelling is often restricted by limited technical capacity and fragmented datasets; thus, the use of complex models that require equally complex datasets and skills may not be locally appropriate and/or available. Therefore, the primary objective of this study was to calibrate and test the ability of the FAO AquaCrop model, which has comparatively simple input requirements and is relatively easy to use, to simulate peanut (Arachis hypogaea) production in common lowland rice soils under different irrigation regimes. In 2015/16, a field trial was conducted at Phone Ngam Rice Research Centre at Pakse in Champasak province, southern Laos to collate a robust agronomic dataset that could be used to assess the use of AquaCrop as a tool to adequately model peanut production in these environments. Results showed that the model performance in soils commonly found in the rice-based lowland systems was good under well-watered conditions when simulating canopy cover $(\%)$ and aboveground biomass $\left(\mathrm{t} \mathrm{ha}^{-1}\right)\left(n R M S E=24.6 \%\right.$ and $30.6 \mathrm{t} \mathrm{ha}^{-1}$, respectively). However, performance in water-limited conditions was moderate to poor $\left(n R M S E=27.0 \%\right.$ and $35.1 \mathrm{t} \mathrm{ha}^{-1}$; and $44.2 \%$ and $38.8 \mathrm{t} \mathrm{ha}^{-1}$, respectively). Furthermore, the model was unable to simulate soil water with any degree of reliability given the limited lateral water distribution across the root zone, as evidenced by lack of soil water tension sensor response to irrigation and rainfall events, particularly once flowering had occurred. In addition to increased plant water use, the lack of lateral movement can be attributed to the physical characteristics of these hard-setting, sandy soils that are known to collapse soon after cultivation. Therefore, further work is required to thoroughly evaluate the use of AquaCrop to simulate soil water in relation to peanut production in the rice-growing lowland soils of the region. Subsequent experimentation to improve lateral water movement in the root zone, including: (i) the use of organic soil ameliorants; and (ii) irrigation system design may assist in the improved calibration of the soil water component of the model under these conditions. Lastly, as well as being the first assessment of peanut production in Laos, this paper also presents the first reported evaluation of AquaCrop used for the simulated production of peanut (Arachis hypogaea), more widely.
\end{abstract}

Keywords: AquaCrop, peanut, Laos, lowlands, irrigation 
Khov, S. et al., Calibration and validation of AquaCrop for irrigated peanut (Arachis hypogaea) in lowland rice systems of southern Laos

\section{INTRODUCTION}

The Lao People's Democratic Republic (Lao PDR) has some of the highest rates of poverty, food insecurity and poor nutritional status in southeast Asia, particularly within the rural community (World Bank, 2016). In Laos, rain-fed lowlands account for $\sim 80 \%$ of the total rice-production area which occurs mostly in the wet season (Shu \& Ouk, 2013). However, there are opportunities to enhance rural household incomes and improve nutritional status through the intensification of smallholder rice-based systems. This can be accomplished through the diversification from wet season rice monoculture to dry-season field and horticultural crop production in areas where water is available for irrigation or where, following the end of wet season rains, residual soil moisture is sufficient to grow high-value, market-oriented, short duration crops. In addition to limited water availability, there are a number of known biophysical soil constraints that are typical of the rice-growing lowlands within the region and that may impede successful production of the aforementioned crop species. These include strongly acidic, sandy soils bereft of organic matter and low water holding and nutrient retention capacity due to low clay content and low cation exchange capacity. To increase the productivity and profitability of these systems, inputs such as lime/gypsum, fertiliser and soil ameliorants are required which can often be prohibitively expensive for the average smallholder. Therefore, a balance between optimal rates of input addition and affordability must be obtained which can be achieved, in part, through the use of crop models designed specifically to simulate the interactive effects of varying environmental conditions (e.g. soils and climate) and agricultural management strategies (e.g. fertiliser and irrigation application) (Homayounfar et al., 2014).

Whilst there are numerous models that are designed to simulate the biophysical processes of crop production (see Kersebaum et al., 2007), many are complex and have large data requirements. In less-developed regions, datasets are often fragmented or non-existent and technical capacity is limited. Therefore, models that are relatively simple to use with minimal input data that is readily available or easy to obtain may be a more useful analytical tool for technical staff, water managers, policy makers and other end-users in less developed countries such as Laos (Vote et al., 2015). One such model is AquaCrop, an empirical process-based, dynamic crop-growth model developed by the Food and Agriculture Organisation (FAO) to simulate biomass and yield response of field and vegetable crops to water under different environmental conditions and management strategies (Steduto et al., 2012; Steduto et al., 2008). AquaCrop has been used extensively in different regions around the world to identify the crop response to water stress and varying irrigation depth, namely in northern Iran (e.g. Khoshravesh et al., 2012), in southern Italy (e.g. Todorovic et al., 2009), in northern Ethiopia (e.g. Araya et al., 2010), in Kenya (e.g. Ndambuki, 2013), and India (e.g. Abedinpour et al., 2012); to improve field management of small scale farming (e.g. Ngetich et al., 2012); and to predict yield under future water availability scenarios (e.g. Abedinpour et al., 2014; Mainuddin et al., 2010; Mainuddin et al., 2013; Mainuddin et al., 2011; Mainuddin et al., 2012). However, a review of the literature reported very few studies of crop production specific to Laos using the AquaCrop model, and certainly none that have reported the use of AquaCrop to simulate peanut (Arachis hypogaea) production, either in Laos or worldwide. Therefore, the aim of this study was to evaluate the use of AquaCrop to simulate peanut production grown with 'best' agronomic practises in the rice-growing lowlands of southern Laos.

\section{MATERIALS AND METHOD}

\subsection{Location of study site, experimental design and management}

A randomised complete block design, replicated three times, was adopted for this experiment which was conducted at Phone Ngam Rice Research Centre (PNG) in Pakse, Champasak province in southern Laos (Figure 1). The total experimental area was $\sim 332 \mathrm{~m}^{2}$ and each plot was $6 \mathrm{~m} \mathrm{x} 4.2 \mathrm{~m}\left(\sim 25.2 \mathrm{~m}^{2}\right)$ with 7 beds per plot, a $1 \mathrm{~m}$ guard row between plots and a $2 \mathrm{~m}$ buffer zone between replicated blocks ( 3 replications $\mathrm{x} 3$ irrigation treatments $=9$ plots $)$. Following the formation of beds, the site was irrigated with a hand sprinkler and fertiliser (15:15:15 NPK) was banded along the centre of each bed at a depth of $\sim 3.0 \mathrm{~cm}$ at a rate of 25 $\mathrm{kg} \mathrm{rai}^{-1}$. On 19/12/2015, freshly harvested peanut seeds of a local variety purchased from a local market in Bolikhamxay province were sown into hand-made hollows at a depth of $\sim 2.5 \mathrm{~cm}$ along two rows located at the edges of each bed (row and hill spacing was $\sim 0.30 \mathrm{~m}$ and $0.25 \mathrm{~m}$, respectively). Whilst the exact origin of the variety is unknown, it is speculated that it is a Valencia-type with 3+ kernels per pod, based on plant structure and pod/kernel formation (Wright G, personal communications, 27 April 2016). Following sowing, the site was hand watered daily to facilitate germination, at which point a calendar schedule was adopted to implement three varying furrow irrigation treatments: high frequency (every Monday and Friday; W1); moderate frequency (every Monday; W2) and least frequency ( every ten days; W3). Pesticide was applied $\sim 06 / 01 / 2016$ after evidence of insect damage was found. Hand-weeding was conducted approximately every two weeks to reduce weed competition for water and nutrients. 
Khov, S. et al., Calibration and validation of AquaCrop for irrigated peanut (Arachis hypogaea) in lowland rice systems of southern Laos

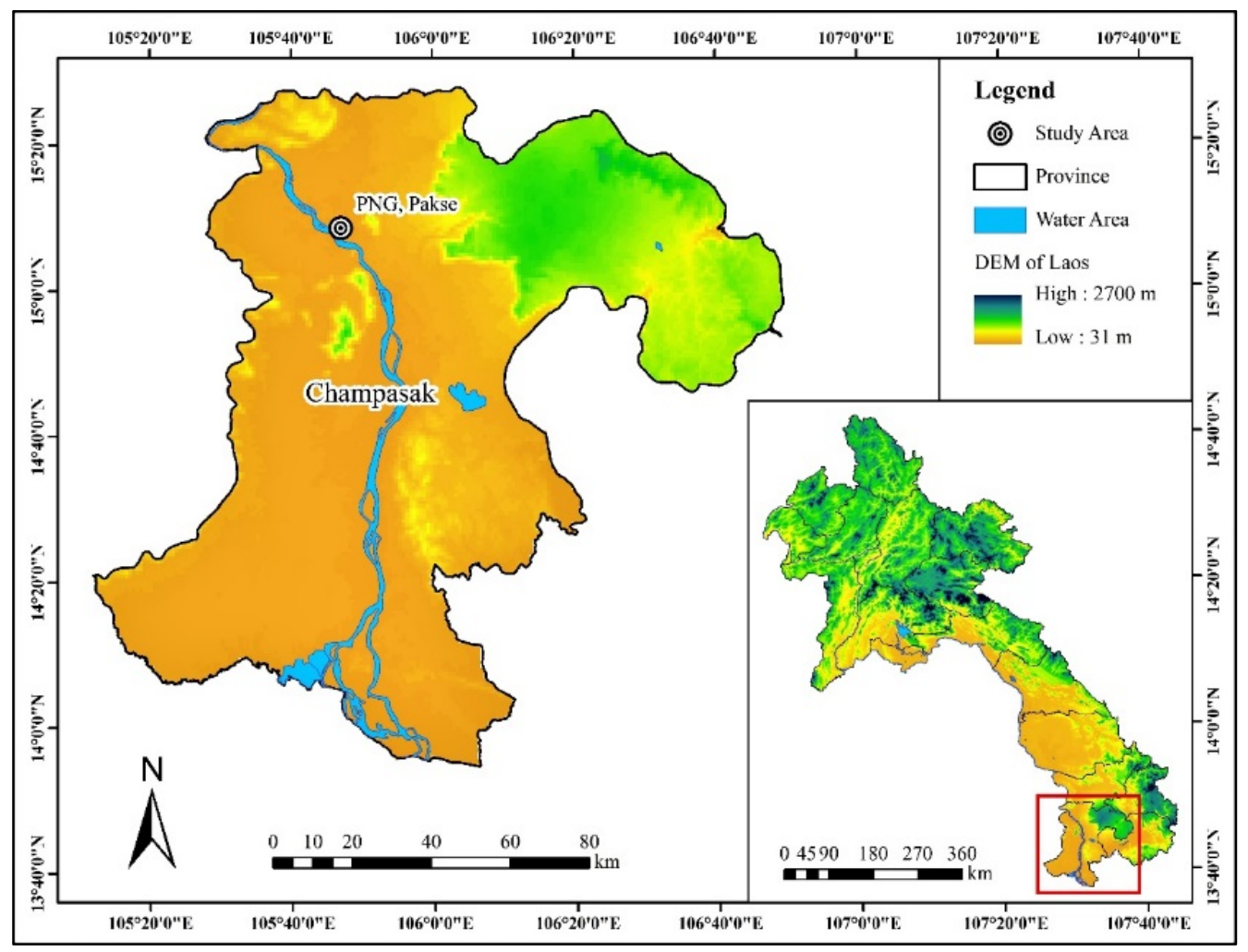

Figure 1. Location of PNG research station, Pakse, Champasak Province

\subsection{AquaCrop model input requirements and data collection}

Climate data

Minimum meteorological input requirements for AquaCrop (v 5.0) include daily temperature, wind speed, solar radiation, relative humidity and rainfall which was recorded by an automatic weather station (AWS) located on-site. AquaCrop also required mean atmospheric carbon dioxide $\left(\mathrm{CO}_{2}\right)$ concentrations for which the default file from Moana Loa, Hawaii, USA was used. Estimates of daily reference evapotranspiration $\left(\mathrm{ET}_{\mathrm{o}}\right)$ were calculated within the model using the input meteorological variables. Where data records were missing (19 - 31/12/2015), substitute agro-climatological data was sourced from NASA POWER ${ }^{1}$ dataset.

Soil data, irrigation volumes and water quality

Soils from each plot were sampled at three depths $(0-20 \mathrm{~cm}, 20-40 \mathrm{~cm}$ and $40-60 \mathrm{~cm})$ pre-land preparation and at $0-20 \mathrm{~cm}$ after planting to characterise the physiochemical properties of the soils. Hydraulic characteristics of the soil were derived using the USDA Soil Water Characteristics application (v. 6.02.74). Soil water tension was monitored using two soil moisture sensors (Watermark, MEA, Australia) which were installed in each plot at $\sim 15 \mathrm{~cm}$ and $45 \mathrm{~cm}$ depth. Irrigation volumes were recorded manually with an in-line flow meter (Multi-Jet Water Meter, ARAD Ltd., Dalia, Israel) and water quality was monitored throughout the season.

\section{Phenological development, aboveground biomass, canopy cover and final yield}

Phenological development was monitored throughout the season and sampling for aboveground biomass (ABV) was conducted when $50 \%$ of plants within each plot reached: flowering; pegging; and pod development. All plants located within a pre-defined sampling area $(n=28)$ were harvested for ABV from which sub-samples were taken $(\sim 1 \mathrm{~kg})$, fresh weights recorded and dried in an oven at $80{ }^{\circ} \mathrm{C}$ for 48 hours. Dry weights were recorded and dry ABV for each plot was estimated. Canopy cover was monitored regularly throughout the season using the freely-available smartphone application, Canopeo (Oklahoma State University, Stillwater, OK, USA) whereby images taken at three randomly selected locations within each plot were used to determine the average value. All plots were harvested from the remaining sampling area $(\sim 10.0$ $\mathrm{m}^{-2}$ ) between $31 / 03 / 2017-21 / 04 / 2017$ based on a maturity assessment conducted on $23-24 / 03 / 2017$ and

${ }^{1}$ https://power.larc.nasa.gov/common/php/POWER_AboutAgroclimatology.php 
Khov, S. et al., Calibration and validation of AquaCrop for irrigated peanut (Arachis hypogaea) in lowland rice systems of southern Laos

fresh weights of yield components (ABV and pods) were recorded. Sub-samples of each harvest component ( $3 \times 1 \mathrm{~kg}$ per plot) were oven-dried at $80^{\circ} \mathrm{C}$ for 48 hours and dry weights recorded.

\subsection{Model calibration, validation and performance assessment}

A performance assessment of the AquaCrop model was conducted through the course of calibration and validation whereby simulated canopy cover $(\mathrm{CC})$, crop transpiration $\left(\mathrm{T}_{\mathrm{r}}\right), \mathrm{ABV}$, and yield under non-limiting conditions (i.e. zero water and soil fertility/salinity stress) was compared to field measurements of all three irrigation treatments. As expected, the treatment with the highest frequency of irrigation (W1) was closest when comparing $\mathrm{CC}$ and was used to calibrate the model through an iterative process of adjusting sensitive parameters based on field observations. Each input adjustment was then run with the corresponding climate, soil, field observation and irrigation files and the resulting statistical indicators of the model were scrutinised for performance. Once calibrated, the two remaining irrigation treatments (W2 and W3) were used to validate model performance under varying levels of water stress. Goodness-of-fit was evaluated using the statistical indicators: root mean square error ( $R M S E)$, normalised root mean square error ( $n R M S E)$, Pearsons correlation coefficient $(r)$, model efficiency coefficient $(E)$, and Willmott's index of agreement $(d)$ built into the model and described in detail elsewhere (e.g. Greaves \& Wang, 2016; Hadebe et al., 2017).

\section{RESULTS}

\subsection{Environmental conditions and irrigation volumes}

Soil sampling showed that soils at $0-40 \mathrm{~cm}$ consisted mostly of sandy loam with some clay soils $(>20 \%)$ at $40-60 \mathrm{~cm}$ (Table 1). The soils were bereft of organic matter and the bulk density (data not shown) was high, particularly at $0-20 \mathrm{~cm}$. Physical inspection of the soils confirmed the existence of a hardpan between $0-$ $40 \mathrm{~cm}$ (also not shown). Pre-lime application, the soils were strongly acidic and mean $\mathrm{pH}$ at $0-20 \mathrm{~cm}$ was 4.13; after the incorporation of lime, mean $\mathrm{pH}$ increased by 1.57 units.

Table 1. Soil composition and hydraulic characteristics

\begin{tabular}{lccccccccc}
\hline \multirow{2}{*}{$\begin{array}{l}\text { Depth } \\
\text { (cm) }\end{array}$} & Sand & Silt & Clay & OM & Texture & Sat & FC & PWP & Ksat (mm/day) \\
\hline $0-20$ & 60 & 10 & 30 & 0.51 & Sandy loam & 27.5 & 13.8 & 6.3 & 176.8 \\
$20-40$ & 58 & 13 & 29 & 0.28 & Sandy loam & 26.9 & 15.6 & 8.0 & 97.5 \\
$40-60$ & 54 & 21 & 25 & 0.21 & Sandy clay loam & 27.2 & 20.7 & 12.7 & 18.3 \\
\hline
\end{tabular}

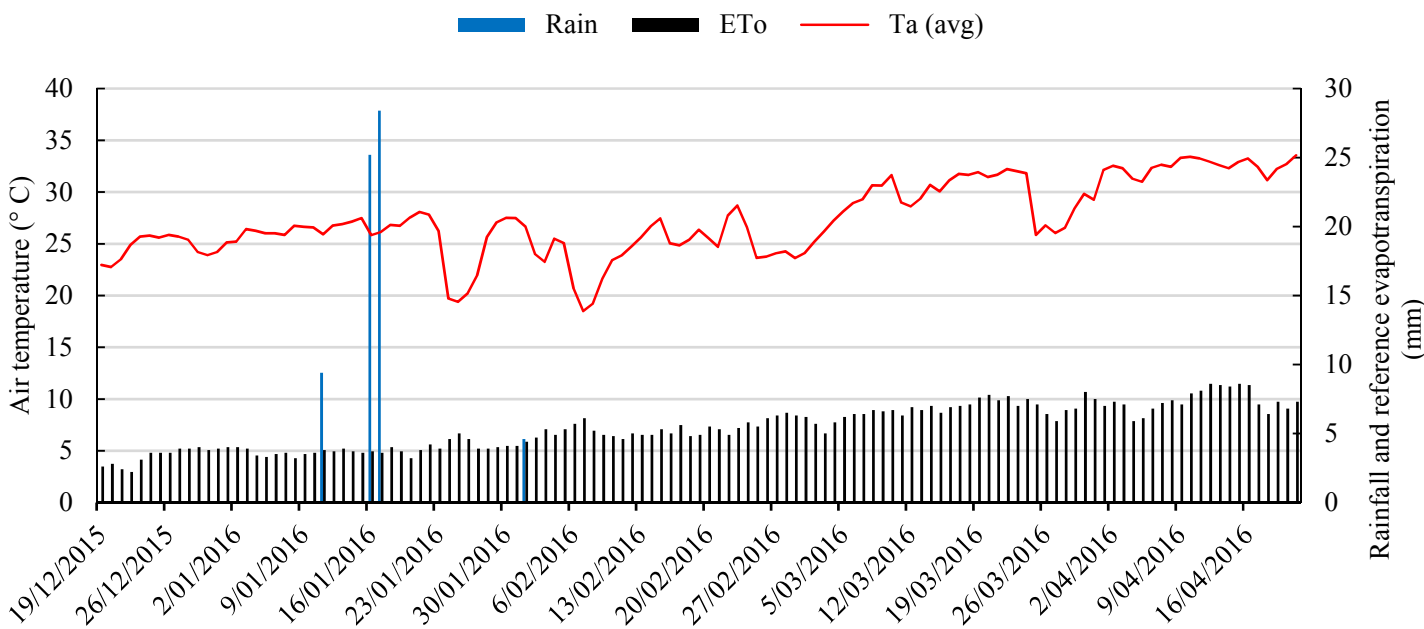

Figure 2. Average daily air temperatures $\left({ }^{\circ} \mathrm{C}\right)$, total daily rainfall $(\mathrm{mm})$ and reference evapotranspiration (mm) observed at PNG research station (19/12/2015 - 21/04/2016).

The average daily air temperature $\left(\mathrm{T}_{\mathrm{a}}\right)$ over the growing season was $29.8{ }^{\circ} \mathrm{C}$; the minimum and maximum average daily $\mathrm{T}_{\mathrm{a}}$ were $18.5{ }^{\circ} \mathrm{C}$ and $33.6{ }^{\circ} \mathrm{C}$ and occurred on the $07 / 02 / 2016$ and $21 / 04 / 2016$, respectively (Figure 2). Large, unseasonal rainfall events occurred in the early part of the growing season and on $16-$ 
Khov, S. et al., Calibration and validation of AquaCrop for irrigated peanut (Arachis hypogaea) in lowland rice systems of southern Laos

17/01/2016, a combined total of $53.6 \mathrm{~mm}$ was received. As expected, the evaporative demand of the atmosphere increased as the season progressed and seasonal $\mathrm{ET}_{\mathrm{o}}$ was $681 \mathrm{~mm}$.

Soil water tension measured at $15 \mathrm{~cm}$ and $45 \mathrm{~cm}$ depth during the early vegetative stage remained relatively steady at $\sim 10 \mathrm{kPa}$ within each plot (data not shown). Towards the end of January/early February 2016, soil water tension declined fairly rapidly and dropped below the lower limit of sensor

\begin{tabular}{|c|c|c|c|}
\hline \multicolumn{3}{|c|}{$-10-0$} & capability $(<-500 \mathrm{kPa})$ within the first week of furrow irrigation; by mid-season, \\
\hline & & $\infty$ & soil water at $45 \mathrm{~cm}$ depth had also depleted beyond the sensor limit which \\
\hline & & a. ก & $\begin{array}{l}\text { 1ndicated that lateral water movement from the furrow to the centre of the bed, } \\
\text { where the sensor was located, was limited. This was further evidenced by minimal }\end{array}$ \\
\hline & & $\pi$ का & response to irrigation events and was most likely attributed to inadequate refilling \\
\hline & & 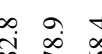 & of the root zone as a result of compacted sandy loam soils with very little organic \\
\hline & & & $\begin{array}{l}\text { matter and limited water holding capacity. The average cumulative total of } \\
\text { irrigation water applied was } 403 \mathrm{~mm}, 231 \mathrm{~mm} \text { and } 149 \mathrm{~mm} \text { to W1, W2 and W3 }\end{array}$ \\
\hline & & în & $\begin{array}{l}\text { respectively. Throughout the season, irrigation water quality was excellent and } \\
\text { observations of electrical conductivity }(\mathrm{EC}) \text { were } \leq 0.31 \mathrm{dS} / \mathrm{m} \text {. }\end{array}$ \\
\hline
\end{tabular}

\subsection{Canopy cover, aboveground biomass and final yield}

Table 2 presents the percentage of canopy over of each treatment measured throughout most of the cropping season. As shown, the treatment that received the most frequent irrigation (W1) had a greater percentage of canopy cover compared to those irrigated less frequently (W2 and W3). ABV sampled at flowering (20 25 January 2016), pegging (09 February 2016) and pod development (07 March 2016) followed a similar trend (data not shown). Unfortunately, unintended progressive grazing events by roaming livestock occurred between the period $09 / 03-09 / 04 / 2016$ severely impacted CC and ABV with an estimated loss of 15 $\%$ and $10 \%$, respectively $(\sim 26 / 03-02 / 04 / 2016)$; and a further $70 \%$ and $60 \%$, respectively $(\sim 09 / 04-21 / 04 / 2016)$. The total estimated CC and ABV loss was $\sim$ $85 \%$ and $70 \%$, respectively, and was accounted for during the simulation. Mean pod yield of each irrigation treatment was $\sim 1.75$ ton $\mathrm{ha}^{-1}, 0.87$ ton ha-1 $\mathrm{ha}^{-1}$ and 1.04 ton $\mathrm{ha}^{-1}$ for $\mathrm{W} 1, \mathrm{~W} 2$, and $\mathrm{W} 3$, respectively. As seed yield was not measured, it was estimated based on average kernel-to-pod ratio of 0.70 (Wright G, personal communications, 04/05/2017 - see Section 3.3.)

\subsection{Model calibration and validation}

The calibration of the model focused primarily on normalised water productivity $\left(W P^{*}\right.$; default value $=17 \mathrm{~g} \mathrm{~m}^{-2}$ and calibrated value $=13 \mathrm{~g} \mathrm{~m}^{-2}$ ) of the system based on two considerations: (i) field observations of decreased water use efficiency via evaporation of pooled irrigation water that remained in furrows after each irrigation event because of limited lateral water movement given the physical properties of the soil, including the hardpan; and (ii) due to the fact that some leguminous crop species have $W P^{*}<15 \mathrm{~g} \mathrm{~m}^{-2}$ due to processes of biological nitrogen fixation (Raes et al., 2012).

An evaluation of the final model calibration and validation is given in Table 3 . The results of the calibration procedure showed that the model was able to simulate canopy cover and biomass production under the well-watered conditions of the higher frequency irrigation treatment (W1) as indicated by the relatively high $d$ and low RMSE (Greaves \& Wang, 2016). Simulated and observed estimates of final ABV were $3.23 \mathrm{tha}^{-1}$ and $3.43 \mathrm{tha}^{-1}$, respectively; and simulated versus observed seed yield were $1.29 \mathrm{t} \mathrm{ha}^{-1}$ and $1.23 \mathrm{t} \mathrm{ha}^{-1}$, respectively. Note that simulations of soil moisture content were not considered for both calibration and validation given that actual soil moisture within the root zone could not be accurately measured (see Section 3.1).

Validation results showed that model performance was reduced under varying levels of water stress. The statistical indicators showed that simulations of CC and ABV had moderate to fair agreement with field observations for the treatment with the least irrigation frequency (W3) and the treatment with the mid-frequent 
Khov, S. et al., Calibration and validation of AquaCrop for irrigated peanut (Arachis hypogaea) in lowland rice systems of southern Laos

application of irrigation (W2), respectively. Simulated versus observed estimates of final ABV for W2 were $2.15 \mathrm{t} \mathrm{ha}^{-1}$ and $1.67 \mathrm{tha}^{-1}$; and $1.27 \mathrm{t} \mathrm{ha}^{-1}$ and $2.34 \mathrm{t} \mathrm{ha}^{-1}$ for W3. Simulated versus observed estimates of grain yield for W2 were $0.85 \mathrm{t} \mathrm{ha}^{-1}$ and $0.61 \mathrm{t} \mathrm{ha}^{-1}$; and $0.45 \mathrm{t} \mathrm{ha}^{-1}$ and $0.73 \mathrm{t} \mathrm{ha}^{-1}$ for $\mathrm{W} 3$. As shown, observed CC, ABV and grain yield of W2 was consistently lower than that of W3 and may be attributed to a sharp drop in air-temperature $\left(\sim 10{ }^{\circ} \mathrm{C}\right.$ between $21 / 01 / 2016$ and $\left.25 / 02 / 2016\right)$ which coincided with flowering of W2 and triggered suspension of flowering and may have altered resource priority of the plants, most likely affecting subsequent pod development which resulted in lower yields observed within this particular treatment (Wade L, personal communications, 08/06/2016).

Table 3. Statistical evaluation of model calibration and validation

\begin{tabular}{|c|c|c|c|c|c|c|}
\hline \multirow{2}{*}{$\begin{array}{l}\text { Statistical } \\
\text { indicator }\end{array}$} & \multicolumn{2}{|c|}{ W1 } & \multicolumn{2}{|c|}{ W2 } & \multicolumn{2}{|c|}{ W3 } \\
\hline & CC $(\%)$ & $\operatorname{ABV}\left(\mathrm{tha}^{-1}\right)$ & CC $(\%)$ & $\operatorname{ABV}\left(\mathrm{tha}^{-1}\right)$ & $\mathrm{CC}(\%)$ & $\operatorname{ABV}\left(\mathrm{tha}^{-1}\right)$ \\
\hline$r$ & 0.92 & 0.94 & 0.85 & 1.00 & 0.90 & 0.95 \\
\hline$R M S E$ & 13.7 & 0.7 & 18.7 & 0.6 & 14.1 & 0.6 \\
\hline nRMSE & 24.6 & 30.6 & 44.2 & 38.8 & 27.0 & 35.1 \\
\hline$E$ & 0.65 & 0.70 & 0.00 & 0.49 & 0.61 & 0.56 \\
\hline
\end{tabular}

\section{CONCLUSIONS}

The results of this study showed that the FAO AquaCrop model could satisfactorily simulate canopy cover, aboveground biomass and final yield of peanut (Arachis hypogaea) in the rice-growing lowlands of southern Laos under well-watered conditions. The study also showed that the model could predict peanut production with a degree of reliability under water-limited conditions. However, the statistical indicators suggested that the treatment that received water $\sim 10$ days $(\mathrm{W} 3$; total cumulative irrigation $=149 \mathrm{~mm}$ ) was more accurately simulated than that which received irrigation every Monday and Friday (W2; total cumulative irrigation = $231 \mathrm{~mm}$ ), most likely attributed to decreased biomass production within W2 as a result of cold-stress at flowering. Therefore, the model should be further evaluated to determine whether the FAO AquaCrop model can adequately simulate peanut (Arachis hypogaea) production with varying levels of water-stress in these environments. Furthermore, ways to improve lateral water movement and/or monitoring of water in the sandy loam soils common in the rice-growing lowlands within the region should be investigated so that a thorough evaluation of model performance can be achieved. Subsequent experiments that explore the use of organic soil ameliorants (rice straw and animal manure); and irrigation system design to improve lateral distribution of water in these soils will assist in this process.

\section{ACKNOWLEDGEMENTS}

This study was funded by the Australian Centre for International Agricultural Research (ACIAR) project entitled 'Improving water and nutrient management to enable double cropping in the rice growing lowlands of Lao PDR and Cambodia' [SMCN/2012/071]. The authors would like to thank all project staff and students who assisted in the establishment of the experiment and data collection for this study, particularly the technical staff at Phone Ngam Rice Research Centre. The authors would also like to extend gratitude to former Charles Sturt University students, Ms Harriet Brickhill and Ms Jillian Lyall, who were funded by the Australian Government through the New Colombo Plan Mobility Grant and assisted with the management and monitoring of the experiment. Many thanks to Professor Lester Burgess, NSW Co-ordinator of The Crawford Fund, for his technical experience and advice with respect to pest and disease identification and management; and lastly, but not certainly not least, Mr Soknith Chreok, for his patient guidance and time spent with junior research staff and students. 
Khov, S. et al., Calibration and validation of AquaCrop for irrigated peanut (Arachis hypogaea) in lowland rice systems of southern Laos

\section{REFERENCES}

Abedinpour, M., Sarangi, A., Rajput, T., \& Singh, M. (2014). Prediction of maize yield under future water availability scenarios using the AquaCrop model. The Journal of Agricultural Science, 152(04), 558-574.

Abedinpour, M., Sarangi, A., Rajput, T., Singh, M., Pathak, H., \& Ahmad, T. (2012). Performance evaluation of AquaCrop model for maize crop in a semi-arid environment. Agricultural Water Management, 110, 55-66.

Araya, A., Habtu, S., Hadgu, K. M., Kebede, A., \& Dejene, T. (2010). Test of AquaCrop model in simulating biomass and yield of water deficient and irrigated barley (Hordeum vulgare). Agricultural Water Management, 97(11), 1838-1846.

Greaves, G. E., \& Wang, Y.-M. (2016). Assessment of FAO AquaCrop Model for Simulating Maize Growth and Productivity under Deficit Irrigation in a Tropical Environment. Water, 8(12), 557.

Hadebe, S. T., Modi, A. T., \& Mabhaudhi, T. (2017). Calibration and testing of AquaCrop for selected sorghum genotypes. Water $S A, 43,209-221$.

Homayounfar, M., Lai, S. H., Zomorodian, M., Sepaskhah, A. R., \& Ganji, A. (2014). Optimal crop water allocation in case of drought occurrence, imposing deficit irrigation with proportional cutback constraint. Water resources management, 28(10), 3207-3225.

Kersebaum, K., Hecker, J.-M., Mirschel, W., \& Wegehenkel, M. (2007). Modelling water and nutrient dynamics in soil-crop systems: a comparison of simulation models applied on common data sets. In K. Kersebaum, J.-M. Hecker, W. Mirschel \& M. Wegehenkel (Eds.), Modelling water and nutrient dynamics in soil-crop systems (pp. 1-17): Springer Netherlands.

Khoshravesh, M., Mostafazadeh-Fard, B., Heidarpour, M., \& Kiani, A.-R. (2012). AquaCrop model simulation under different irrigation water and nitrogen strategies. Water Science and Technology, 67(1), 232-238.

Mainuddin, M., Hoanh, C. T., Jirayoot, K., Halls, A. S., Kirby, M., Lacombe, G., \& Srinetr, V. (2010). Adaptation options to reduce the vulnerability of Mekong water resources, food security and the environment to impacts of development and climate change, Water for a Healthy Country Flagship Report Series, 152

Mainuddin, M., Kirby, M., \& Chu Thai, H. (2013). Impact of climate change on rainfed rice and options for adaptation in the lower Mekong Basin. Natural Hazards, 66(2), 905-938. doi: 10.1007/s11069-0120526-5

Mainuddin, M., Kirby, M., \& Hoanh, C. T. (2011). Adaptation to climate change for food security in the lower Mekong Basin. Food Security, 3(4), 433-450. doi: 10.1007/s12571-011-0154-z

Mainuddin, M., Mac, K., \& Hoanh, C. T. (2012). Water productivity responses and adaptation to climate change in the lower Mekong basin. [Article]. Water International, 37(1), 53-74. doi: 10.1080/02508060.2012.645192

Ndambuki, J. (2013). Application of AquaCrop model in deficit irrigation management of cabbages in Keiyo Highlands. International Journal of Water Resources and Environmental Engineering, 5(7), 360369.

Ngetich, K. F., Raes, D., Shisanya, C. A., Mugwe, J., Murcheru-Muna, M., Mugendi, D. N., \& Diel, J. (2012). Calibration and validation of AquaCrop model for maize in sub-humid and semi-arid regions of central highlands of Kenya. Research Application Summary, 1525-1547.

Raes, D., Steduto, P., Hsiao, T., \& Fereres, E. (2012). AquaCrop Version 4.0: Chapter 3 Calculation Procedures: FAO, Land and Water Division, Rome, Italy

Shu, F., \& Ouk, M. (2013). Increased productivity of rainfed lowland rice cropping systems of the Mekong region. Crop and Pasture Science, 63(10), 944-973.

Steduto, P., Hsiao, T. C., Fereres, E., \& Raes, D. (2012). Crop yield response to water, 66, Irrigation and Drainage Paper, Food and Agriculture Organisation of the United Nations, 505

Steduto, P., Raes, D., Hsiao, T. C., Fereres, E., Heng, L., Izzi, G., \& Hoogeveen, J. (2008). AquaCrop: a new model for crop prediction under water deficit conditions. In A. López-Francos (Ed.), Drought management: scientific and technological innovations (Vol. 80, pp. 285-292): Zaragoza : CIHEAM.

Todorovic, M., Albrizio, R., Zivotic, L., Saab, M.-T. A., Stöckle, C., \& Steduto, P. (2009). Assessment of AquaCrop, CropSyst, and WOFOST models in the simulation of sunflower growth under different water regimes. Agronomy Journal, 101(3), 509-521.

Vote, C., Oeurng, C., Ty, S., Phongpacith, C., Inthavong, I., Seng, V., Eberbach, P., \& Hornbuckle, J. (2015). A comparison of three empirical models for assessing cropping options in a data-sparse environment, with reference to Laos and Cambodia, ACIAR Technical Reports, 30

World Bank. (2016). World Development Indicators 2016. Washington D.C. 